\title{
Angiogenic activity of maternal and fetal placental tissues of ewes throughout gestation
}

\author{
D. S. Millaway, D. A. Redmer, J. D. Kirsch, R. V. Anthony* and \\ L. P. Reynolds \\ Department of Animal and Range Sciences, North Dakota State University, Fargo, North Dakota \\ 58105, USA; and *Department of Animal Science, University of Missouri Columbia, Columbia, \\ Missouri 65211, USA
}

\begin{abstract}
Summary. In Study 1, explants of caruncular and intercaruncular endometrium and fetal membrane were collected from ewes (5-6/day) on Days 11-13, 16-18 and 21-23 after mating and Days 10-12 after oestrus, and incubated for $24 \mathrm{~h}$. Explantconditioned media were evaluated for their effects on endothelial cell proliferation. Both caruncular and intercaruncular endometrium secreted factor(s) which stimulated endothelial cell proliferation, and which appeared to be $>100 \times 10^{3} M_{\mathrm{r}}$ and heat-labile. In Study 2, conditioned media from explant incubations of caruncular and intercaruncular endometrium, cotyledon and intercotyledonary fetal membrane obtained from ewes (6-7/day) on Days $40,65,90,115$ and 140 after mating were evaluated for their effects on endothelial cell proliferation. Caruncular and intercaruncular endometrium and intercotyledonary fetal membrane secreted factor(s) which inhibited endothelial cell proliferation. Media from cotyledonary explants tended to stimulate endothelial cell proliferation on Day 115. Conditioned media from cotyledonary explants obtained from 3 additional ewes at Day 120 of gestation stimulated endothelial cell proliferation, and this activity also appeared to be $>100 \times 10^{3} M_{\mathrm{r}}$. Placental angiogenesis in ewes therefore appears to be modulated by both maternal and fetal placental tissues via stimulatory and inhibitory factors.
\end{abstract}

Keywords: angiogenesis; endothelial proliferation; placenta; ewe; gestation

\section{Introduction}

The ruminant placenta is divided into placentomes comprised of maternal caruncular endometrium and fetal cotyledon, and also into interplacentomal areas comprised of intercaruncular endometrium and intercotyledonary fetal membrane (Ramsey, 1982). In the ewe, the blastocyst begins to expand by Days 11-13 after mating (Bindon, 1971; Guillomot et al., 1981) and attaches to the uterine mucosa by Days 15-18 (Davies \& Wimsatt, 1966; Boshier, 1969; Guillomot et al., 1981). Interdigitation of fetal membrane (presumptive cotyledon) with maternal caruncles begins by Days 22-25 (Davies \& Wimsatt, 1966; Boshier, 1969) and can be considered as the initial stage of implantation. Several major events occur in the interval between attachment and implantation, including rapid growth of uterine glands, extensive vascularization both of maternal and fetal placental tissues, and marked increases in uterine blood flow (Greiss \& Anderson, 1970; Reynolds et al., 1984). These events serve to supply nutrients to the developing conceptus via absorption of uterine glandular secretions by the fetal membranes as well as, at later stages, physiological exchange between maternal and fetal capillaries.

Placental weight increases until about Day 90 of gestation in ewes; thereafter placental weight remains constant or decreases whereas fetal weight continues to increase exponentially (Barcroft, 
1946; Evans \& Sack, 1973; Rattray et al., 1974). Although placental weight stops increasing, placental vasculature of ewes continues to grow and develop throughout most of gestation (Barcroft, 1946; Barcroft \& Barron, 1946; Teasdale, 1976) concomitant with increased rates of uterine and umbilical blood flows (Makowski et al., 1968; Rosenfeld et al., 1974). This continued growth and development of placental vasculature during late gestation supports the increasing metabolic demands of fetal growth.

Growth and development of placental vasculature may be influenced by local products. Human (Burgos, 1983; Fuchs et al., 1985) and bovine (Reynolds et al., 1987; Reynolds \& Redmer, 1988) placental tissues have been shown to secrete factor(s) which stimulate angiogenesis. Knowledge of factors which influence placental vascular development should lead to better understanding of how fetal and maternal tissues interact for maintaining optimal fetal growth.

The goals of these studies were to determine whether angiogenic factor(s) is produced by sheep placental tissues, which tissue(s) produces such factor(s), and whether the tissue source of activity changes with stage of gestation. Effects of media from culture of placental tissues on proliferation of endothelial cells were used as an indication of angiogenic activity, since we have previously shown close agreement between this assay and other in-vitro and in-vivo assays for angiogenic activity (Reynolds et al., 1987; Reynolds \& Redmer, 1988).

\section{Materials and Methods}

Materials. Dulbecco's Modified Eagle medium (DMEM), Eagle's Minimal Essential medium (EMEM), MEM nonessential amino acids, calf serum, fetal bovine serum (FBS), and penicillin-streptomycin (10000 U penicillin G sodium $/ \mathrm{ml}$ and $10000 \mu \mathrm{g}$ streptomycin sulphate $/ \mathrm{ml}$ ) were purchased from Gibco (Grand Island, NY, USA). Bovine pancreatic insulin and antibiotic-antimycotic $(10000 \mathrm{U}$ penicillin/ml, $10 \mathrm{mg}$ streptomycin $/ \mathrm{ml}, 25 \mu \mathrm{g}$ amphotericin $\mathrm{B} / \mathrm{ml}$ ) were purchased from Sigma (St Louis, MO, USA). $\left[{ }^{3} \mathrm{H}\right]$ Leucine $\left(1-\left[4,5 \cdot{ }^{3} \mathrm{H}(\mathrm{N})\right]\right.$ leucine) was purchased from New England Nuclear (Boston, MA, USA). Dialysis membranes were obtained from Spectrum Medical Industries (Los Angeles, CA, USA). Ultrafiltration membranes and pressurized ultrafiltration cell were from Amicon (Lexington, MA, USA). Bovine aortic endothelial cells were the same cell line and same passage number described by Reynolds et al. (1987). Protein concentrations of pools of conditioned media were determined by using the method of Lowry et al. (1951) with bovine serum albumin (fraction V) as the standard.

Study 1. Samples $(\sim 1 \mathrm{~g})$ of caruncular and intercaruncular endometrium and fetal membrane were obtained from ewes slaughtered on Days 10-12 $(\mathrm{N}=5)$ after oestrus and Days 11-13 $(\mathrm{N}=6), 16-18(\mathrm{~N}=6)$ and 21-23 $(\mathrm{N}=6)$ after mating. Explants $(88 \pm 29 \mathrm{mg})$ of each tissue were minced and incubated in $5 \mathrm{ml}$ EMEM as described by Reynolds et al. (1987). To minimize the number of samples to process, three pools ( $2-6$ ewes per pool) of explantconditioned media were made for each tissue within each day of gestation; and, within each day of gestation, no ewe being represented in all three pools. The pools of conditioned media were lyophilized and reconstituted at half the initial volume with distilled $\mathrm{H}_{2} \mathrm{O}$. To remove molecules of small molecular weight (e.g. prostaglandins), which potentially may influence angiogenesis (Form \& Auerbach, 1983), the reconstituted pools of media were dialysed (Spectra/Por 6, $1000 M_{\mathrm{r}}$ cutoff) against 1000 volumes of EMEM ( 3 changes of buffer, with $24 \mathrm{~h}$ dialysis each) at $4^{\circ} \mathrm{C}$. These pools of explant-conditioned media were then assayed for effects on proliferation of bovine aortic endothelial cells as previously described (Reynolds \& Redmer, 1988; Redmer et al., 1988). Briefly, bovine aortic endothelial cells were preincubated for $24 \mathrm{~h}$ in 24 -well plates $\left(20 \times 10^{3}\right.$ cells/well) in medium containing $10 \%$ fetal bovine serum and $10 \%$ calf serum. After preincubation $\left(37^{\circ} \mathrm{C}, 95 \%\right.$ air $5 \% \mathrm{CO}_{2}$ ), medium was changed to serum-free medium (DMEM) containing $20 \%$ unconditioned EMEM (control, 3 wells/plate) or $20 \%$ pooled explant-conditioned medium ( 3 wells/ sample). After an additional $72 \mathrm{~h}$, a Coulter counter was used to determine number of endothelial cells per well.

To determine approximate molecular size of angiogenic activities, an additional pool (5-6 ewes per pool) was made of non-lyophilized, non-dialysed explant-conditioned media from caruncular and intercaruncular endometrium and fetal membrane from each day of gestation. These pools were subjected to ultrafiltration as described by Reynolds et al. (1987) to obtain fractions of $<10,>10,<30,>30,<100$ and $>100 \times 10^{3} M_{\mathrm{r}}$. In addition, $1 \mathrm{ml}$ of each pool was heat-treated $\left(80^{\circ} \mathrm{C}, 30 \mathrm{~min}\right)$ to determine whether angiogenic activity was heat-labile. Unfractionated pools, $M_{\mathrm{r}}$ fractions and heat-treated pools were used in the endothelial cell proliferation bioassay ( 3 wells/fraction or treatment) as described above.

Study 2. Samples $(\sim 1 \mathrm{~g})$ of caruncular and intercaruncular endometrium, cotyledon and intercotyledonary fetal membrane were obtained from ewes slaughtered on Days $40(\mathrm{~N}=7), 65(\mathrm{~N}=7), 90(\mathrm{~N}=7), 115(\mathrm{~N}=6)$ and 140 $(\mathrm{N}=7)$ after mating. Explants $(107 \pm 5 \mathrm{mg})$ of each tissue were minced and incubated as above and three pools (3-7 ewes per pool) of explant-conditioned media were made for each tissue within each day of gestation, as in Study 1. Pools of conditioned media were lyophilized, reconstituted, dialysed, and assayed for effects on proliferation of endothelial cells as in Study 1. 
Since 2 of 3 pools of explant-conditioned media from cotyledons on Day 115 appeared to stimulate $(P<0 \cdot 10)$ proliferation of endothelial cells, cotyledonary explants $(\sim 25 \mathrm{~g})$ were obtained from each of 3 additional ewes on Day 120 after mating. Explants were minced and incubated in $500 \mathrm{ml}$ EMEM as described above. The resulting explantconditioned media were pooled and dialysed (Spectra/Por 3, 3500 $M_{\mathrm{r}}$ cutoff) against 1000 volumes distilled $\mathrm{H}_{2} 0$ at $4^{\circ} \mathrm{C}$, as described above. Retentates were lyophilized, reconstituted in EMEM, and ultrafiltered as described above. Unfractionated and fractionated explant-conditioned media were then assayed for their abilities to stimulate proliferation of endothelial cells.

Validation of explant incubations. In both experiments, a duplicate explant (113 $\pm 13 \mathrm{mg}$ ) of each tissue from 3-4 ewes in each group was minced and incubated in $5 \mathrm{ml}$ EMEM in which leucine was limited $(10 \%$ of that in EMEM described above). Before incubation, $15 \mu \mathrm{Ci}\left[{ }^{3} \mathrm{H}\right]$ leucine in $20 \mu 10.01 \mathrm{~N}-\mathrm{HCl}$ were added to each explant. At 8 , 18, and $24 \mathrm{~h}$ of incubation, $0.25 \mathrm{ml}$ samples of media were removed and stored at $-80^{\circ} \mathrm{C}$. These aliquants were diluted to $2 \mathrm{ml}$ with distilled $\mathrm{H}_{2} \mathrm{O}$ and dialysed (1000 $M_{\mathrm{r}}$ cutoff) against 1000 volumes phosphate buffered saline (0.01 M-sodium phosphate, $\left.0.14 \mathrm{M}-\mathrm{NaCl}, 0.003 \mathrm{~N}-\mathrm{NaN}_{3}, \mathrm{pH} 7.4\right)$ at $4^{\circ} \mathrm{C}$, as described above. Radioactivity remaining after dialysis was determined for $0.5 \mathrm{ml}$ samples of each retentate by liquid scintillation counting (Beckman LS100, Beckman Instruments, Fullerton, CA, USA) and is reported as pmol $\left[{ }^{3} \mathrm{H}\right]$ leucine incorporated into non-dialysable product per gram incubated tissue.

Statistical analysis. Data were analysed statistically by using least-squares analysis of variance, with effects of day of cycle or gestation, tissue and day $\times$ tissue interaction included in the model (SAS, 1985). When an F-test was significant $(P<0 \cdot 05)$, differences between specific means were evaluated by using Bonferroni's $t$ test (Kirk, 1968). In addition, means for individual pools were compared with control (unconditioned media) values by $t$ test (Steel \& Torrie, 1960). Data are reported as means \pm s.e.m. expressed as percentage of control values $\left(55.8 \pm 5.6 \times 10^{3}\right.$ cells/ well after $72 \mathrm{~h}$ incubation, $n=15$ plates).

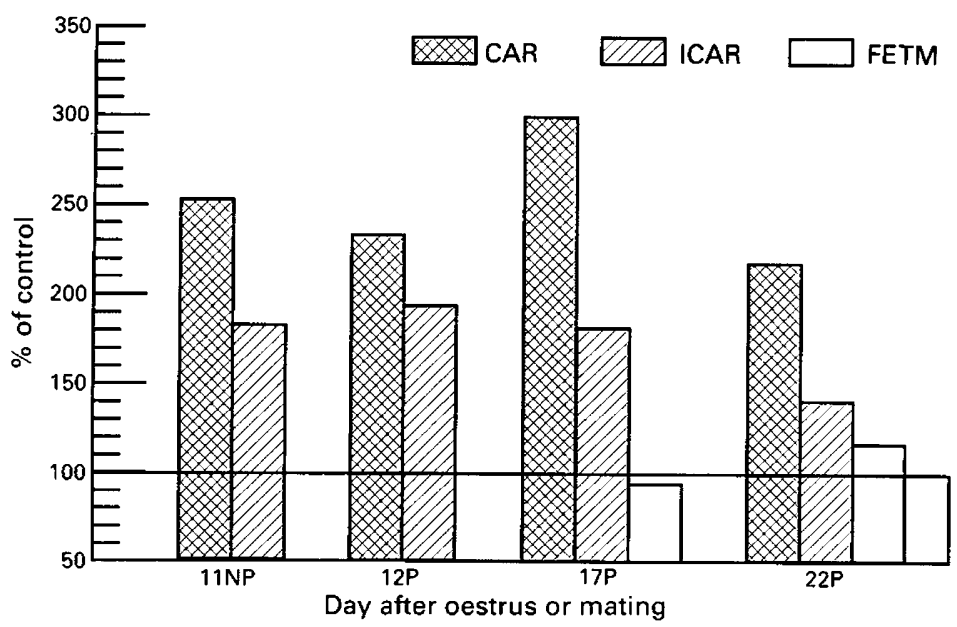

Fig. 1. Effect of media conditioned by explants of placental tissues from Study 1 on proliferation of endothelial cells. Values are expressed as $\%$ of control (unconditioned) media. CAR, caruncular; ICAR, intercaruncular; FETM, fetal membrane tissues; NP = non-pregnant ewes; $\mathrm{P}=$ pregnant ewes. Residual standard deviation (square root of error mean square) equals $39 \cdot 1 \%$.

\section{Results}

Incorporation of $\left[{ }^{3} \mathrm{H}\right]$ leucine into non-dialysable product over time was linear for each tissue across all days of the cycle or pregnancy $(P<0.01$ for caruncular and intercaruncular endometrium, cotyledon and intercotyledonary tissue; $P<0.07$ for fetal membrane). Concentrations of protein in conditioned media pools did not change with day of cycle or early pregnancy in Study 1 and averaged $344 \pm 25,193 \pm 9$ and $295 \pm 56 \mu \mathrm{g} / \mathrm{ml}$ for media conditioned by caruncular, intercaruncular and fetal membrane explants. Concentrations of protein in media pools also did not change across day of gestation in Study 2 and were $381 \pm 21,339 \pm 30,467 \pm 41$ and $159 \pm 21 \mu \mathrm{g} / \mathrm{ml}$ for media conditioned by caruncular, intercaruncular, cotyledonary and intercotyledonary explants. 
Table 1. Effects of untreated and fractionated conditioned media from caruncular and intercaruncular explants on proliferation of endothelial cells*

\begin{tabular}{|c|c|c|c|c|c|}
\hline \multirow[b]{2}{*}{ Tissue } & \multirow{2}{*}{$\begin{array}{c}M_{\mathrm{r}} \text { fraction } \\
\left(\times 10^{-3}\right)\end{array}$} & \multicolumn{4}{|c|}{ Day after oestrus or mating $\dagger$} \\
\hline & & $11 \mathrm{NP}$ & $12 \mathrm{P}$ & $17 \mathrm{P}$ & $22 \mathbf{P}$ \\
\hline Caruncular & $\begin{array}{c}\text { Untreated } \\
<10 \\
>10 \\
<30 \\
>30 \\
<100 \\
>100\end{array}$ & $\begin{array}{l}290 \cdot 3 \\
102 \cdot 1 \\
292 \cdot 6 \\
104 \cdot 8 \\
299 \cdot 5 \\
112 \cdot 9 \\
270 \cdot 4\end{array}$ & $\begin{array}{r}212 \cdot 5 \\
90 \cdot 2 \\
213 \cdot 4 \\
92 \cdot 0 \\
176 \cdot 0 \\
88 \cdot 0 \\
206 \cdot 5\end{array}$ & $\begin{array}{r}219 \cdot 8 \\
97 \cdot 2 \\
216 \cdot 8 \\
93 \cdot 6 \\
264 \cdot 8 \\
98 \cdot 0 \\
239 \cdot 7\end{array}$ & $\begin{array}{r}229 \cdot 0 \\
120 \cdot 6 \\
212 \cdot 6 \\
97 \cdot 2 \\
160 \cdot 3 \\
116 \cdot 7 \\
180 \cdot 8\end{array}$ \\
\hline $\begin{array}{l}\text { Inter- } \\
\text { caruncular }\end{array}$ & $\begin{array}{c}\text { Untreated } \\
\quad<10 \\
>10 \\
<30 \\
>30 \\
<100 \\
>100\end{array}$ & $\begin{array}{r}125 \cdot 3 \\
95 \cdot 8 \\
142 \cdot 4 \\
104 \cdot 9 \\
132 \cdot 5 \\
93 \cdot 0 \\
131 \cdot 0\end{array}$ & $\begin{array}{r}149 \cdot 5 \\
121 \cdot 1 \\
181 \cdot 8 \\
96 \cdot 4 \\
194 \cdot 3 \\
93 \cdot 3 \\
116 \cdot 7\end{array}$ & $\begin{array}{l}132 \cdot 8 \\
131 \cdot 4 \\
127 \cdot 1 \\
110 \cdot 4 \\
129 \cdot 6 \\
128 \cdot 6 \\
119 \cdot 0\end{array}$ & $\begin{array}{r}98 \cdot 5 \\
78 \cdot 2 \\
113 \cdot 8 \\
107 \cdot 8 \\
125 \cdot 2 \\
105 \cdot 9 \\
113 \cdot 3\end{array}$ \\
\hline
\end{tabular}

*Values as $\%$ of control (unconditioned) media.

$\dagger \mathbf{N P}=$ non-pregnant ewes; $\mathbf{P}=$ pregnant ewes.

Table 2. Effects of untreated and heat-treated explantconditioned media on proliferation of endothelial cells*

\begin{tabular}{|c|c|c|c|c|c|}
\hline \multirow[b]{2}{*}{ Tissuet } & \multirow[b]{2}{*}{ Treatment } & \multicolumn{4}{|c|}{ Day after oestrus or mating $\ddagger$} \\
\hline & & $11 \mathrm{NP}$ & $12 \mathrm{P}$ & $17 \mathrm{P}$ & $22 \mathrm{P}$ \\
\hline CAR & $\begin{array}{l}\text { Untreated } \\
\text { Heat-treated }\end{array}$ & $\begin{array}{l}213 \cdot 9 \\
107 \cdot 0\end{array}$ & $\begin{array}{r}203 \cdot 2 \\
93 \cdot 1\end{array}$ & $\begin{array}{l}231 \cdot 4 \\
105 \cdot 1\end{array}$ & $\begin{array}{r}158 \cdot 3 \\
91 \cdot 6\end{array}$ \\
\hline ICAR & $\begin{array}{l}\text { Untreated } \\
\text { Heat-treated }\end{array}$ & $\begin{array}{r}119 \cdot 2 \\
89 \cdot 8\end{array}$ & $\begin{array}{r}143 \cdot 1 \\
90 \cdot 0\end{array}$ & $\begin{array}{l}155 \cdot 0 \\
105 \cdot 6\end{array}$ & $\begin{array}{r}125 \cdot 6 \\
84 \cdot 6\end{array}$ \\
\hline FETM & $\begin{array}{l}\text { Untreated } \\
\text { Heat-treated }\end{array}$ & - & - & $\begin{array}{l}106 \cdot 9 \\
104 \cdot 3\end{array}$ & $\begin{array}{l}109 \cdot 2 \\
106 \cdot 6\end{array}$ \\
\hline
\end{tabular}

*Values as \% of control (unconditioned) media.

†CAR, caruncular; ICAR, intercaruncular; FETM, fetal membrane.

$\ddagger N P=$ non-pregnant ewes; $P=$ pregnant ewes.

\section{Study 1}

Although tissue had a significant $(P<0.01)$ effect, day of cycle or early gestation had no effect in the statistical model, nor was there a day $\times$ tissue interaction. Compared with control (unconditioned) media, media conditioned by caruncular and intercaruncular endometrial explants from all groups stimulated $(P<0.01)$ proliferation of endothelial cells, with activity of caruncular endometrium being greater $(P<0.05)$ than that of intercaruncular endometrium across all groups $(249 \pm 18$ vs $174 \pm 12 \%$, Fig. 1). Explant-conditioned media from fetal membrane had no effect on proliferation of endothelial cells (104 $\pm 11 \%$, Fig. 1). After ultrafiltration, mitogenic activity of caruncular explants was present in fractions $>10,>30$, and $>100 \times 10^{3} M_{\mathrm{r}}$ and absent in fractions $<10,<30$, and $<100 \times 10^{3} M_{\mathrm{r}}$ (Table 1). Mitogenic activity of intercaruncular endometrium also appeared to be $>100 \times 10^{3} M_{\mathrm{r}}$, although some discrepancies were observed and endothelial cell proliferation was only slightly $(P<0 \cdot 10)$ stimulated by untreated media 


\section{CAR QZZICAR COT $\square$ C $\square$ ICOT}

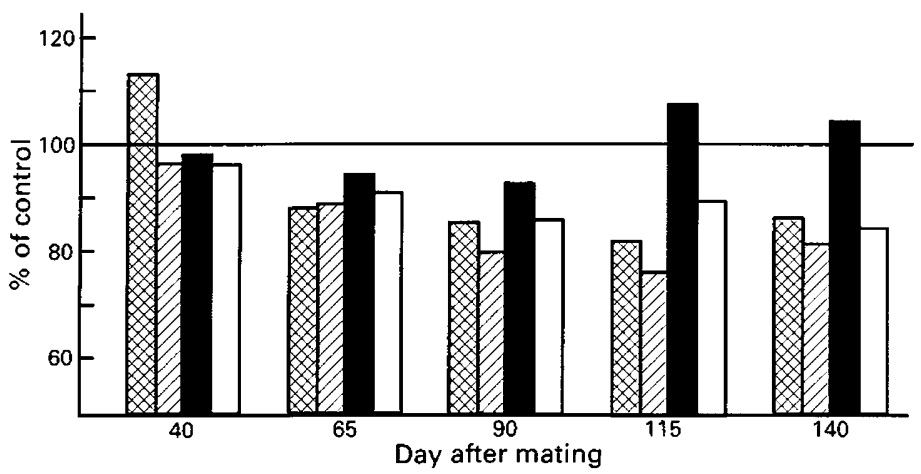

Fig. 2. Effect of media conditioned by explants of placental tissues from late pregnancy on proliferation of endothelial cells. Values are expressed as \% of control (unconditioned) media. CAR, caruncular; ICAR, intercaruncular; COT, cotyledon; ICOT, intercotyledonary fetal membrane tissues. Residual standard deviation (square root of error mean square) equals $11 \cdot 0 \%$.

Table 3. Effects of untreated and fractionated conditioned media from caruncular and cotyledonary explants (from 3 ewes on Day 120 of gestation) on proliferation of endothelial cells*

\begin{tabular}{ccc}
\hline $\begin{array}{l}M_{\mathrm{r}} \text { fraction } \\
\left(\times 10^{-3}\right)\end{array}$ & $\begin{array}{c}\text { Caruncular } \\
\text { explants }\end{array}$ & $\begin{array}{c}\text { Cotyledonary } \\
\text { explants }\end{array}$ \\
\hline Untreated & $92 \cdot 5$ & $215 \cdot 1$ \\
$<10$ & $90 \cdot 1$ & $98 \cdot 0$ \\
$>10$ & $104 \cdot 0$ & $204 \cdot 4$ \\
$<30$ & $106 \cdot 4$ & $108 \cdot 7$ \\
$>30$ & $93 \cdot 6$ & $206 \cdot 4$ \\
$<100$ & $84 \cdot 1$ & $94 \cdot 8$ \\
$>100$ & $98 \cdot 4$ & $172 \cdot 2$ \\
\hline
\end{tabular}

*Values as $\%$ of control (unconditioned) media.

$(126 \pm 11 \%$, Table 1$)$. Untreated or fractionated conditioned media from fetal membrane had no effect on proliferation of endothelial cells (overall $96 \pm 4 \%$ ) compared with unconditioned media. In addition, mitogenic activities of caruncular and intercaruncular endometrium were heat-labile (Table 2).

\section{Study 2}

Compared with control (unconditioned) media, explant-conditioned media of caruncular and intercaruncular endometrium and intercotyledonary fetal membrane inhibited $(P<0.05)$ endothelial cell proliferation, and these activities were not influenced by day of late gestation (Fig. 2). In addition, a tissue $x$ day of gestation interaction was not observed. The mean response (across day of gestation) of endothelial cells to cotyledonary explant-conditioned media was not different from control media (Fig. 2), although 2 of 3 pools of media from cotyledonary explants on Day 115 stimulated $(P<0 \cdot 10)$ endothelial cell proliferation. In addition, samples of 
cotyledonary-conditioned media from Day 115 stimulated endothelial cell proliferation in a dosedependent manner $(89,129,158$ and $139 \%$ of controls for $5,10,20$ and $40 \%$ conditioned media, respectively, $n=2$ ). Pooled media from cotyledonary explants obtained from the 3 ewes on Day 120 of gestation also stimulated $(P<0.05)$ endothelial cell proliferation $(215 \pm 16 \%)$ compared with control media. After ultrafiltration, this activity remained in the $>10,>30$, and $>100 \times 10^{3} M_{r}$ fractions (Table 3).

\section{Discussion}

The angiogenic factor(s) secreted by caruncular and intercaruncular endometrium from early gestation and cotyledon from Day 120 of gestation appears to have an $M_{\mathrm{r}}$ value of $>100 \times 10^{3}$. In addition, the angiogenic activities of caruncular and intercaruncular endometrium were heat-labile. These observations suggest that the active molecule(s) may be a protein. However, ultrafiltration and heat treatment are only preliminary procedures. Several angiogenic molecules from other tissues have been found to have an $M_{\mathrm{r}}$ of $200-800$ and bound to a carrier molecule of about $100 \times 10^{3}$ $M_{\mathrm{r}}$, whereas other reported angiogenic molecules have an $M_{\mathrm{r}}$ ranging from 15 to $30 \times 10^{3}$ (Findlay, 1986). Further purification will therefore be required to elucidate the identity of the active fractions reported in the present studies.

From the present results, it can be concluded that, in early gestation, angiogenic activity is secreted primarily by maternal tissues. In addition, maternal placentomal tissue (caruncular endometrium) exhibited greater activity than did interplacentomal tissue (intercaruncular endometrium). It also seemed that stimulation of angiogenesis by placental tissues was greater early than late in gestation. During early pregnancy, the vascular architecture which supports placental growth and development, secretion of histotroph by uterine glands, and increased uterine blood flow is being established. These events are probably essential for survival of the conceptus, and, indeed, most prenatal mortality in the ewe occurs during the first 30 days of gestation (Quinlivan et al., 1966). In addition, in humans, early embryonic death is often associated with failure of chorionic vascularization (Meegdes et al., 1988).

Effects of endometrial tissues on proliferation of endothelial cells gradually changed from positive in early gestation to negative in mid-gestation. Activity from caruncular endometrium was stimulatory for endothelial cell proliferation through Day 22, decreased to slightly stimulatory at Day 40 , and was inhibitory by Day 65 . Stimulatory activity from intercaruncular endometrium appeared to be decreasing as early as Day 22 , and activity was inhibitory by Day 40 . Fetal membrane had no effect on endothelial cell proliferation in early gestation, whereas intercotyledonary fetal membrane exhibited inhibitory activity in late gestation. In contrast with the other three placental tissues, fetal cotyledon appeared to stimulate angiogenesis around Day 120 of gestation. During the second half of gestation in the ewe placentomal weight does not increase (Barcroft, 1946) but placentomal vasculature continues to develop (Barcroft, 1946; Barcroft \& Barron, 1946). Teasdale (1976) reported increased numbers of endothelial cells in the fetal portion of the placentome (cotyledon) during late gestation. This agrees with our observation that Day- 120 cotyledon secreted factor(s) which stimulated proliferation of endothelial cells. Local secretion of inhibitory factor(s) by maternal placental tissues and inter-cotyledonary fetal membrane may act to prevent further growth of vascular beds in these placental tissues and thus prevent rampant growth of placental microvasculature. This proposal seems reasonable since rampant growth of microvasculature is associated with pathological conditions, and is prevented by local secretion of inhibitory factors (Folkman \& Klagsburn, 1987).

Maintenance of placental vasculature is equally important to pre- and post-natal survival since treatments that reduce fetal growth are also associated with reduced rates of uterine and umbilical blood flows (Christenson \& Prior, 1978) which have been shown to be primary determinants of fetal oxygen and nutrient uptakes (Reynolds et al., 1985, 1986). In addition, Alexander (1964) 
reported a positive correlation between birthweight and weight of placentomes, and birthweight is a key factor in determining postnatal survival and growth in lambs (Huffman et al., 1985). Thus, growth and maintenance of placental vasculature probably play important roles in the establishment and maintenance of the metabolic supply of the fetus, and hence in pre- and post-natal survival and growth. Placental angiogenesis appears to be modulated by both maternal and fetal tissues throughout gestation via stimulatory and inhibitory factors.

We thank M. Hankel for care of animals; D. W. Zaeske for assistance at slaughter; and J. Berg for typing the manuscript. Supported, in part, by PHS grant HD22559 to D.A.R. and L.P.R. Journal Article No. 1720 of the North Dakota Agricultural Experiment Station, Projects 1780 and 1782, and Journal Article No. 10743 of the Missouri Agricultural Experiment Station, Project 431.

\section{References}

Alexander, G. (1964) Studies on the placenta of the sheep. Placental size. J. Reprod. Fert. 7, 289-305.

Barcroft, J. (1946) Researches on Prenatal Life. C.C. Thomas, Springfield.

Barcroft, J. \& Barron, D.H. (1946) Observations on the form and relations of the maternal and fetal vessels in the placenta of the sheep. Anat. Rec. 94, 569-595.

Bindon, B.M. (1971) Systematic study of preimplantation stages of pregnancy in the sheep. Aust. J. biol. Sci. 24, I31-147.

Boshier, D.P. (1969) A histological and histochemical examination of implantation and early placentome formation in sheep. J. Reprod. Fert. 19, 51-61.

Burgos, H. (1983) Angiogenic and growth factors in human amnio-chorion and placenta. Eur. J. clin. Invest. 13, 289-296.

Christenson, R.K. \& Prior, R.L. (1978) Uterine blood flow and nutrient uptake during late gestation in ewes with different number of fetuses. J. Anim. Sci. 46, 189-200.

Davies, J. \& Wimsatt, W.A. (1966) Observation on the fine structure of the sheep placenta. Acta anat. 65, 182-223.

Evans, H.E. \& Sack, W.O. (1973) Prenatal development of domestic and laboratory mammals: growth curves, external features and selected references. Anat. Histol. Embryol. 2, 11-45.

Findlay, J.K. (1986) Angiogenesis in reproductive tissues. J. Endocr. 111, 357-366.

Folkman, J. \& Klagsburn, M. (1987) Angiogenic factors. Science, N.Y. 235, 442-447.

Form, D.M. \& Auerbach, R. (1983) $\mathrm{PGE}_{2}$ and angiogenesis. Proc. Soc. exp. Biol. Med. 172, 214-218.

Fuchs, A., Lindenbaum, E. \& Marcoudas, N.G. (1985) Location of the angiogenic activity in the pregnant human uterus. Acta anat. 124, 241-244.

Greiss, F.C. \& Anderson, S.G. (1970) Uterine blood flow during early ovine pregnancy. Am. J. Obstet. Gynecol. 106, 30-38.

Guillomot, M., Flechon, J.E. \& Winterberger-Torres, S. (1981) Conceptus attachment in the ewe: an ultrastructural study. Placenta 2, 169-182.

Huffman, E.M., Kirk, J.H. \& Pappaioanou, M. (1985) Factors associated with neonatal lamb mortality. Theriogenology 24, 163-171.
Kirk, R.E. (1968) Experimental Design: Procedures for the Behavioral Sciences. Wadsworth, Belmont.

Lowry, O.H., Resebrough, N.J., Farr, A.L. \& Randall, R.J. (1951) Protein measurement with the Folin phenol reagent. J. biol. Chem. 193, 265-275.

Makowski, E.L., Meschia, G., Droegemueller, W. \& Battaglia, F.C. (1968) Measurement of umbilical arterial blood flow to the sheep placenta and fetus in utero. Circ. Res. 23, 623-631.

Meegdes, B.H.L.M., Ingenhoes, R., Peeters, L.L.H. \& Exalto, N. (1988) Early pregnancy wastage: relationship between chorionic vascularization and embryonic development. Fert. Steril. 49, 216-220.

Quinlivan, T.D., Martin, C.A., Taylor, W.B. \& Cairney, I.M. (1966) Estimates of pre- and perinatal mortality in the New Zealand Romney Marsh ewe I. Pre- and perinatal mortality in those ewes that conceived to one service. J. Reprod. Fert. 11, 379-390.

Ramsey, E.M. (1982) The Placenta. Praeger, New York.

Rattray, P.V., Garrett, W.M., East, N.E. \& Hinman, N. (1974) Growth, development and compostion of the ovine conceptus and mammary gland during pregnancy. J. Anim. Sci. 38, 613-626.

Redmer, D.A., Grazul, A.T., Kirsch, J.D. \& Reynolds, L.P. (1988) Angiogenic activity of bovine corpora lutea at several stages of luteal development. $J$. Reprod. Fert. 82, 627-634.

Reynolds, L.P. \& Redmer, D.A. (1988) Secretion of angiogenic activity by placental tissues of cows at several stages of gestation. J. Reprod. Fert. 83, 497-502.

Reynolds, L.P., Magness, R.R. \& Ford, S.P. (1984) Uterine blood flow during early pregnancy in ewes: interaction between the conceptus and the ovary bearing the corpus luteum. J. Anim. Sci. 58, 423-429.

Reynolds, L.P., Ferrell, C.L. \& Ford, S.P. (1985) Transplacental diffusion and blood flow of gravid bovine uterus. Am. J. Physiol. 249, 539-543.

Reynolds, L.P., Ferrell, C.L., Robertson, D.A. \& Ford, S.P. (1986) Metabolism of the gravid uterus, foetus and utero-placenta at several stages of gestation in cows. J. agric. Sci., Camb. 106, 437-444.

Reynolds, L.P., Millaway, D.S., Kirsch, J.D., Infeld, J.E. \& Redmer, D.A. (1987) Angiogenic activity of placental tissues in cows. J. Reprod. Fert. 81, 233-240. 
Rosenfeld, C.R., Morriss, F., Makowski, E.L., Meschia, G. \& Battaglia, F.C. (1974) Circulatory changes in the reproductive tissues of ewes during pregnancy. Gynecol. Invest. 5, 252-268.

SAS User's Guide (1985) Statistics, 5th edn., Statistical Analysis System Institute, Cary, NC.
Steel, R.G.D. \& Torrie, J.H. (1960) Principles and Procedures of Statistics. McGraw-Hill, New York.

Teasdale, F. (1976) Numerical density of nuclei in the sheep placenta. Anat. Rec. 185, 187-196.

Received 22 November 1988 